\title{
SPRAY ANTI NYAMUK ( REPELLENT) INFUS KULIT BUAH JERUK NIPIS SEBAGAI ALTERNATIF PENCEGAHAN DEMAM BERDARAH DI MASYARAKAT
}

\author{
Spray Anti Mosquito (Repellent) Infusion Of Orange Fruit Leather \\ As An Alternative To Prevent Blood Fever In The Community
}

\author{
Iin Indawati, Khofifah, Vanessa Michelle \\ Sekolah Tinggi Farmasi Muhammadiyah Cirebon \\ indawatistf@gmail.com
}

\begin{abstract}
ABSTRAK
Penyakit Demam Berdarah Dengue (DBD) merupakan salah satu masalah kesehatan masyarakat yang utama di Indonesia hingga saat ini. Diketahui bahwa di Kabupaten Cirebon hingga minggu kedua bulan Juni 2020 jumlah kasus penderita DBD tercatat sebanyak 463 orang dengan 11 orang meninggal. Disimpulkan bahwa perlu dan pentingnya sosialisasi mengenai pencegahan DBD pada masyarakat Kabupaten Cirebon, salah satu pencegahan dimasyarakat dengan memanfaatkan bahan yang terdapat dirumah melalui edukasi pemanfaatan Kulit Buah Jeruk Nipis sebagai spray anti nyamuk (Repellant). Sasaran kegiatan pengabdian masyarakat ini adalah masyarakat Kabupaten Cirebon. Kegiatan pengabdian kepada masyarakat ini menggunakan metode webinar dengan menyampaikan informasi dengan kegiatan edukasi tentang bahaya DBD dan cara pencegahan. Cara penggunaan serta pembuatan spray infus kulit buah jeruk nipis sebagai anti nyamuk (Repellant). Kegiatan sosialisasi pencegahan dan penggunaan Spray Infus Kulit Buah Jeruk Nipis berjalan dengan lancar. Hal ini ditandai dengan hasil uji hedonic sediaan yang mendapatkan skor rata-rata 3, artinya responden suka dengan sediaan Spray Infus Kulit Buah Jeruk Nipis.
\end{abstract}

Kata Kunci: Demam berdarah, kulit buah jeruk nipis, anti nyamuk

\begin{abstract}
Dengue Hemorrhagic Fever (DHF) is one of the main public health problems in Indonesia to date. It is known that in Cirebon Regency until the second week of June 2020 the number of dengue cases was recorded at 463 people with 11 people dying. It was concluded that the need and importance of socialization regarding the prevention of dengue fever in the people of Cirebon Regency, one of the prevention in the community by utilizing materials available at home is through education on the use of Lime Fruit Skin as an anti-mosquito spray (Repellantt). The target of this community service activity is the people of Cirebon Regency. This community service activity uses the webinar method by conveying information with educational activities about the dangers of dengue and how to prevent it. How to use and manufacture lime peel infusion spray as an anti-mosquito (Repellantt). The socialization activities on the prevention and use of Lime Skin Infusion Spray went well. This is indicated by the results of the hedonic test for the preparation which got an average score of 3 , meaning that the respondents liked the Spray for Lime Skin Infusion.
\end{abstract}

Keywords : Dengue fever, lime rind, mosquito repellent 


\section{PENDAHULUAN}

Penyakit Demam Berdarah Dengue (DBD) merupakan salah satu masalah kesehatan masyarakat utama di Indonesia hingga saat ini. Jumlah penderita dan luas daerah penyebarannya semakin bertambah seiring dengan meningkatnya mobilitas dan kepadatan penduduk. Berdasarkan hasil pengamatan studi literatur, diketahui bahwa di Kabupaten Cirebon hingga minggu kedua bulan Juni 2020 jumlah kasus penderita DBD (Demam Berdarah Dengue) tercatat sebanyak 463 orang dengan 11 orang meninggal (Fathnur Rohman, 2020). Berdasarkan studi tersebut, kami menyimpulkan bahwa perlu dan pentingnya sosialisasi mengenai pencegahan DBD (Demam Berdarah Dengue) pada masyarakat Kabupaten Cirebon yang dapat dengan mudah dan murah dapat dilakukan oleh masyarakat. Salah satu metode sosialisasi melalui edukasi pemanfaatan Kulit Buah Jeruk Nipis sebagai spray anti nyamuk (Repellant) sebagai tujuan kegiatan pengabdian masyarakat.

Penyebab penyakit dari nyamuk Aedes aegypti sangat berbahaya bagi manusia. Nyamuk merupakan serangga yang banyak kita jumpai peranannya sebagai vektor penyakit-penyakit berbahaya bagi manusia misalnya penyakit kaki gajah, malaria dan demam berdarah dengue (Susanti \& Boesri 2012). Pengendalian terhadap nyamuk sebagai vektor penyakit banyak dilakukan yaitu dengan cara menurunkan populasi atau dengan memutus siklus hidupnya (Andriani, 2008). Diantaranya dengan menggunakan antinyamuk kimia sintetis seperti diethyltoluamide (DEET), diclorovinil dimethyl phospat (DDP) malathion, parathion, dan lainlain penggunaan bahan kimia tersebut secara terus menerus, selain berdampak buruk terhadap kesehatan manusia, juga akan membuat nyamuk resisten (Kardinan \& Dhalimi, 2010). Efek samping dari insektisida kimia, dapat dikurangi dengan penggunaan insektisida alami yang berasal dari ekstrak tanaman untuk menggantikan DEET seperti menggunakan bahan alam tumbuhan zodia (Evodia suaveolens), suren (Toona siureni), selasih (Ocimum spp), lavender (Lavendula sp), serai wangi (Andropogon nardus), geranium (Geranium radula) dan jeruk nipis (Citrus aurantifolia). Jenis tumbuhan ini dapat digunakan sebagai insektisida alami karena memiliki minyak atsiri yang tidak disukai oleh nyamuk maupun serangga (Sanjaya, dkk., 2014).

Jeruk Nipis (Citrus aurantifolia) banyak digunakan karena kandungan kimia yang berkhasiat dalam tanaman tersebut. Kulit buah jeruk nipis Citrus aurantifolia dapat digunakan sebagai mengandung senyawa kimia yang merupakan metabolit sekunder seperti minyak atsiri, flavonoid, saponin, steroid, dan terpen. Kandungan minyak atsiri pada kulit jeruk nipis seperti limonen atau limonoid menghambat pergantian kulit pada larva dan dapat masuk ke dalam tubuh larva nyamuk sebagai racun (Ekawati, 2017). 


\section{BAHAN DAN METODE}

Kegiatan pengabdian masyarakat ini menggunakan metode webinar seperti ditunjukkan pada Gambar 1. Materi informasi yang disampaikan dalan kegiatan edukasi diantaranya tentang bahaya dan cara pencegahan DBD. Cara penggunaan spray berupa video serta pembuatan spray infus kulit buah jeruk nipis sebagai anti nyamuk (Repellantt). Dalam metode pembuatan spray infus, peralatan yang digunakan yaitu timbangan analitik, sudip, botol spray, Pisau/gunting, saringan, gelas beaker, batang pengaduk, panci, glass ukur, saringan, dan kertas saring. Bahan yang digunakan sebagai anti nyamuk (Repellant) ini yaitu Kulit Jeruk Nipis (Citrus aurantifolia), Propylenglycol, Ethanol, dan Aquadest.

Menurut Farmakope 1995 untuk mendapatkan infusa dilakukan cara yaitu pertama Kulit buah jeruk nipis dicuci dengan menggunakan air dan dipotong kecil-kecil, kemudian ditimbang sebanyak 100g. Kemudian Kulit buah jeruk nipis dimasukkan kedalam masing-masing panci dan masing-masing ditambahkan aquadest 1000mL. Dipanaskan diatas penangas air selama 15 menit, terhitung mulai dari suhu $90^{\circ} \mathrm{C}$ sambil sesekali diaduk. Dan Infusa disaring menggunakan kertas saring selagi panas. Kemudian Ditambahkan aquadest panas hingga volume infusa $100 \mathrm{~mL}$ (Gambar 2). Sedangkan untuk membuat spray infus kulit jeruk nipis dilakukan dengan cara yaitu Pertama-tama masukkan Infusa Kulit Jeruk Nipis kedalam gelas Beaker tambahkan propilenglikol untuk melarutkan, setelah larut masukkan kedalam wadah spray yang telah di kalibrasi kemudian tambahkan etanol 96\% Ad $100 \mathrm{~mL}$ (Gambar 3).

Uji Organoleptik dilakukan untuk melihat tampilan fisik sediaan dengan cara melakukan pengamatan bentuk warna, bau, dan tekstur dari sediaan yang dibuat. Uji Hedonik disebut juga uji kesukaan dilakukan dengan cara responden diminta tanggapan pribadinya mengenai tingkat kesukaannya, yang disebut skala hedonic, misalnya, dalam hal suka, dapat mempunyai skala hedonic seperti sangat suka sekali, suka sekali, suka, tidak suka, dan sangat tidak suka. Sebaliknya jika tanggapan itu tidak suka dapat berupa sangat tidak suka sekali, sangat tidak suka, tidak suka, dan agak tidak suka.

\section{HASIL}

Melalui kegiatan ini diharapkan masyarakat dapat memahami dan mengerti tentang Demam berdarah Dengue, sekaligus diharapkan masyarakat dapat mengaplikasikan pembuatan spray guna mencegah dan menekan kenaikan Demam berdarah Dengue.

\section{PEMBAHASAN}

Pengamatan organoleptis bertujuan untuk melihat kesesuaian produk jadi secara fisik melalui pengamatan menggunakan indra pengamatan. Seperti warna, bentuk, bau, rasa dan konsistensi. Hasil pengamatan menunjukan bahwa produk spray memiliki bentuk cairan, 
berwarna kuning keruh, memiliki bau khas jeruk nipis, rasa cenderung pahit, dan konsistensi sediaan cair. Hasil Uji Hedonik (Kesukaan) pada responden sebanyak 10 orang menunjukkan positif. Penilaian adalah warna, bau,bentuk dan konsistensi dengan cara menyemprotkan sediaan ke telapak tangan responden dan menanyakan penilaian dari tiap responden. Ada 5 pernyataan yang berbeda untuk penilaian yaitu SSS (Sangat Suka Sekali) dengan skor 5, SS (Suka Sekali) dengan skor 4, S (Suka) dengan skor 3, TS (Tidak Suka) dengan skor 2 dan STS (Sangat Tidak Suka Sekali) dengan skor 1. Dari hasil responden didapatkan skor sebanyak 3. Yang artinya reponden suka terhadap sediaan. Karena bau yang khas jeruk nipis dan nyaman saat digunakan.

\section{KESIMPULAN DAN SARAN}

Kegiatan sosialisasi pencegahan dan penggunaan Spray Infus Buah Jeruk Nipis berjalan dengan lancer. Hal ini ditandai dengan hasil uji hedonic sediaan yang mendapatkan rata-rata 3, artinya respoden suka dengan sediaan Spray Infus Kulit Buah Jeruk Nipis.

\section{UCAPAN TERIMA KASIH}

Terima Kasih Kami ucapkan terutama kepada LPPM Sekolah Tinggi Farmasi Muhammadiyah Cirebon dan seluruh pihak yang telah membantu dan berpartisipasi pada kegiatan pengabdian masyarakat ini.

\section{DAFTAR PUSTAKA}

Andriani, A.,(2008) Uji Potensi Larvasida Fraksi Ekstrak Daun Cinacanthusnuntans L. Terhadap larva Instar III Nyamuk Aedes aegypti., institut Pertanian Bogor. Bogor.

Susanti \& Boesri (2012). Toksisitas Biolarvasida Ekstrak Tembakau dibandinkan Dengan Ekstrak Zodia Terhadap Jentik Vektor Demam Berdarah Dengue. Buletin Penelitian Kesehatan., 40 (No.2).star III Nyamuk Aedes aegypti., institut Pertanian Bogor. Bogor.

Kardinan \& Dhalimi, (2010). Potensi Adas (Foeniculum Vulgare) Sebagai Bahan Aktif Lotion Antinyamuk Demam Berdarah (Aedes aegypti). Bul. Litro, 21(1),61-68.).

Sanjaya, Y., Adisenjaya, Yusuf, H., \& Wijayanti, L. 2014. Efektifitas Daya Tolak Ekstrak Geranium Radula Cavan Terhadap Nyamuk Aedes aegypti. Bionatura , 62-67.

Rohman, Fathnur. 2020. 436 Orang di Kabupaten Cirebon Terkena DBD 11 Meninggal. Okezone.com (diakses pada 20 Juli 2020)

Ekawati, E. R., Santoso, S. D., \& Purwanti, Y. R. 2017. Pemanfaatan Kulit Buah Jeruk Nipis (Citrus aurantifolia) Sebagai Larvasida Aedes aegypti Instar III. Jurnal Biota Vol. 3 No. 1, 2. 
Lampiran Gambar.

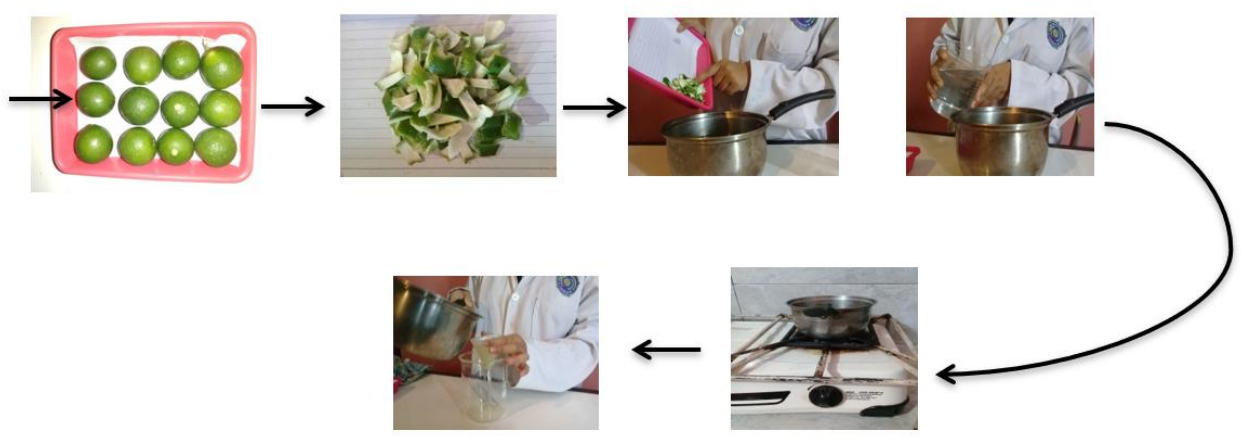

Gambar 1. Proses Pembuatan Inffus Kulit Buah Jeruk Nipis

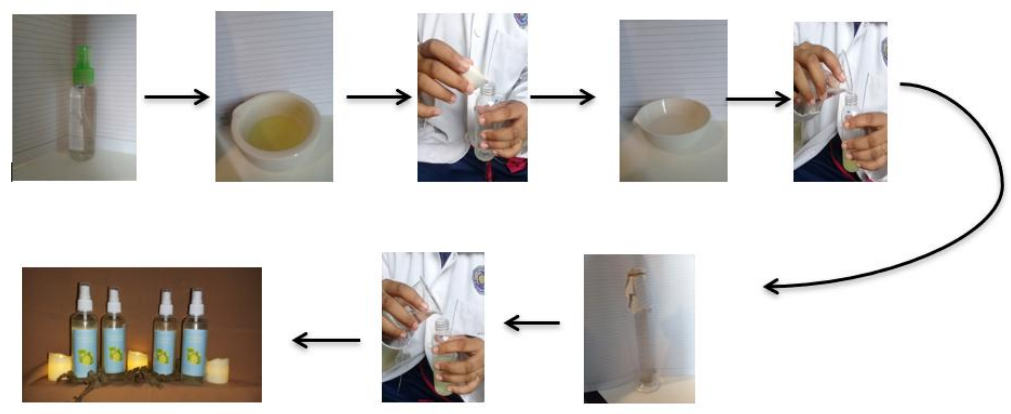

Gambar 2. Proses Pembuatan Spray Infus Buah Jeruk Nipis 
